\title{
Anti-Dumping Policies and Safeguard Measures in the Context of Costa Rica's Economic Liberalization
}

\author{
Ricardo Monge-González* \\ rmonge@caatec.org \\ Francisco Monge-Ariño** \\ monge-arino.1@osu.edu
}

\begin{abstract}
World Bank Policy Research Working Paper 3591, May 2005
The Policy Research Working Paper Series disseminates the findings of work in progress to encourage the exchange of ideas about development issues. An objective of the series is to get the findings out quickly, even if the presentations are less than fully polished. The papers carry the names of the authors and should be cited accordingly. The findings, interpretations, and conclusions expressed in this paper are entirely those of the authors. They do not necessarily represent the view of the World Bank, its Executive Directors, or the countries they represent. Policy Research Working Papers are available online at http://econ.worldbank.org.
\end{abstract}

* Executive Director of Costa Rican High Technology Advisory Committee Foundation (CAATEC) and Professor of International Trade at Universidad Latina de Costa Rica.

** Associate Member of CAATEC and Teaching Assistant at Ohio State University, U.S.A. 


\begin{abstract}
This paper reviews the most important changes, both in the economy and in the legal/institutional framework, to deal with unfair trade practices that Costa Rica has experienced during its trade liberalization process. It also evaluates whether the sectors that as a result of such a process have been facing increased foreign competition, and may have attempted to use the World Trade Organization (WTO) rules adopted by Costa Rica as a protectionist instrument. Costa Rica's legal framework against unfair trade practices at the multilateral level emerged when the country adopted the WTO rules on antidumping policies and safeguard measures. That has been reinforced at the bilateral level through the subscription of free trade agreements with Central America, Mexico, the Dominican Republic, Chile and Canada. So far, only six antidumping petitions and five safeguards have been received by the government. In reviewing these petitions, the government has paid particular attention to the impact of any action on the competitiveness of the domestic market and on the possibility that it would support modernization of the industry. Behind the political acceptance of this disciplined approach lies widespread recognition of the social as well as economic progress that liberalization has supported.
\end{abstract}




\section{INTRODUCTION}

After the economic crisis of the early 1980s, the Government of Costa Rica decided to abandon its import-substitution strategy and move toward integration with the world economy through a gradual process of economic liberalization. During the same period, the country joined international organizations such as the World Trade Organization (WTO) with the purpose of having the legal instruments necessary to protect its commercial interests worldwide. As part of the agreements and commitments made, Costa Rica undertook a significant institutional transformation process in the field of foreign trade, creating institutions to safeguard the commercial rights of its businessmen (producers, exporters and importers) as well as of its citizens.

Now, two decades after the start of the economic liberalization process, we are attempting to analyze the degree to which the country had to face unfair trade practices or to apply safeguard measures due to substantial increases of imports adversely affecting its productive sector. We are also interested in examining the degree to which the sectors that benefited from the previous import-substitution model-sectors that have been facing an increased foreign competition as a result of the elimination of tariff and nontariff barriers to imports-have attempted to make use of the protection mechanisms against unfair practices as a new protectionist instrument.

This paper is organized into four main sections, plus an introduction and final considerations. The first section explores the reasons for the adoption of the new development model based on mid-1980s economic liberalization, the way in which this new model has been implemented and Costa Rica's economic performance during these two decades of implementation. Sections II and III discuss the legal and institutional framework established by Costa Rica in order to respond to the complaints about unfair practices and safeguard measures. The fourth section contains a summary analysis of each of the cases brought before the Ministry of Economy, Industry and Trade by Costa Rica's productive sector. Finally, the section on final considerations summarizes the main findings of the study and their economic policy implications. 


\section{SECTION I}

\section{Economic Liberalization: From Import Substitution to Export Promotion}




\section{1.a What was the motivation for the liberalization of the economy?}

During the 1980s, many events contributed to precipitating the deepest economic crisis in Costa Rica's recent history. This crisis—which, according to González (1989), resulted from a combination of structural and other short-term factors-made it necessary to review the development strategy pursued until then. The structural determinants of the crisis reflected a contradiction between the country's main characteristics (a small domestic market, a relative abundance of a highly-specialized workforce and of natural resources) and the policies adopted as part of the import-substitution development strategy. The commercial policies generated a series of distortions of relative prices, giving rise to an anti-export bias as well as a reduction in the domestic consumers' welfare and in the efficiency of domestic production (Taylor, 1984; Monge and Corrales, 1988). The short-term determinants of the crisis included, most importantly, the oil crisis and the coffee boom of the mid 1970s, followed by the unfortunate domestic policies adopted in response to these events and the international inflation and recession of the late 1970s and early 1980s (González, 1984).

The major macroeconomic indicators deteriorated rapidly between 1981 and 1982 . Inflation reached $80 \%$ per year, the open unemployment rate amounted to $9 \%$ of the workforce, the GDP dropped by $10 \%$ in only one year, there was a sharp devaluation of the colon vis-à-vis the US dollar and the fiscal gap increased significantly (Lizano, 1992). Thus, both the groups that benefited from the import-substitution model and those that were adversely affected by it saw a need for a change of strategy. This situation fostered the adoption of a new economic development plan, the so-called "economic liberalization model", which to this day has not yet become fully effective in Costa Rica. ${ }^{1}$

\section{1.b What did the economic liberalization mean and how was it implemented?}

The economic liberalization model adopted by Costa Rica since the second half of the 1980s seeks a greater integration of the country's economy into the world economy. The objectives are to increase Costa Rica's economic competitiveness in international markets and to provide it with an adequate price system. In order to attain these objectives, a set of reforms was established, which includes a greater opening of the economy to foreign competition by reducing protection for the activities which compete against imports and by eliminating the distortions in the domestic goods and factor markets, all of which reduced directly unproductive, profit-seeking activities (Bhagwati, 1982 and 1991); downsizing and modernizing the state, so that instead of hindering the growth of the private sector it would facilitate its development; granting compensatory subsidies and other incentives to non-traditional exports on a temporary basis, with the purpose of offsetting the anti-export bias generated by the import-substitution model; adopting stable macroeconomic policies, consistent with the liberalization model (Edwards, 1990; IMF,

\footnotetext{
${ }^{1}$ There are still important reforms pending, such as the liberalization in utilities, telecommunications and insurance fields, tax exceptions for some agricultural products and State modernization.
} 
1998 and Mesalles, 1998), and promoting foreign investment by means of incentives characterized by its fiscal nature. ${ }^{2}$

\section{1.c The Response of Costa Rica's Economy to Economic Liberalization: A Long-Term Vision}

Although several studies individually show positive outcomes for Costa Rica's economy during the economic liberalization period, ${ }^{3}$ a comprehensive vision of the performance of that economy in the period under analysis is not available. This section addresses this topic, describing the behavior of Costa Rica's economy during the last two decades (1983-2003) with a focus on trade, employment and poverty, to provide a long-term view of the results achieved through the liberalization of the economy.

First of all, it should be noted that even though Costa Rica eliminated most of its tariff and non-tariff protection in industrial and agricultural activities, the process was carried out gradually. As shown in Figure 1.1, since 1986, when the first tariff reduction and simplification of the protectionist system took place, there was a rapid response in terms of trade flows. In fact, imports began increasing in a significant and sustained manner as did exports, the latter as a response of the export sector to the reduction of the anti-export bias generated by the import-substitution model (liberalization of imports and subsidies to exports).

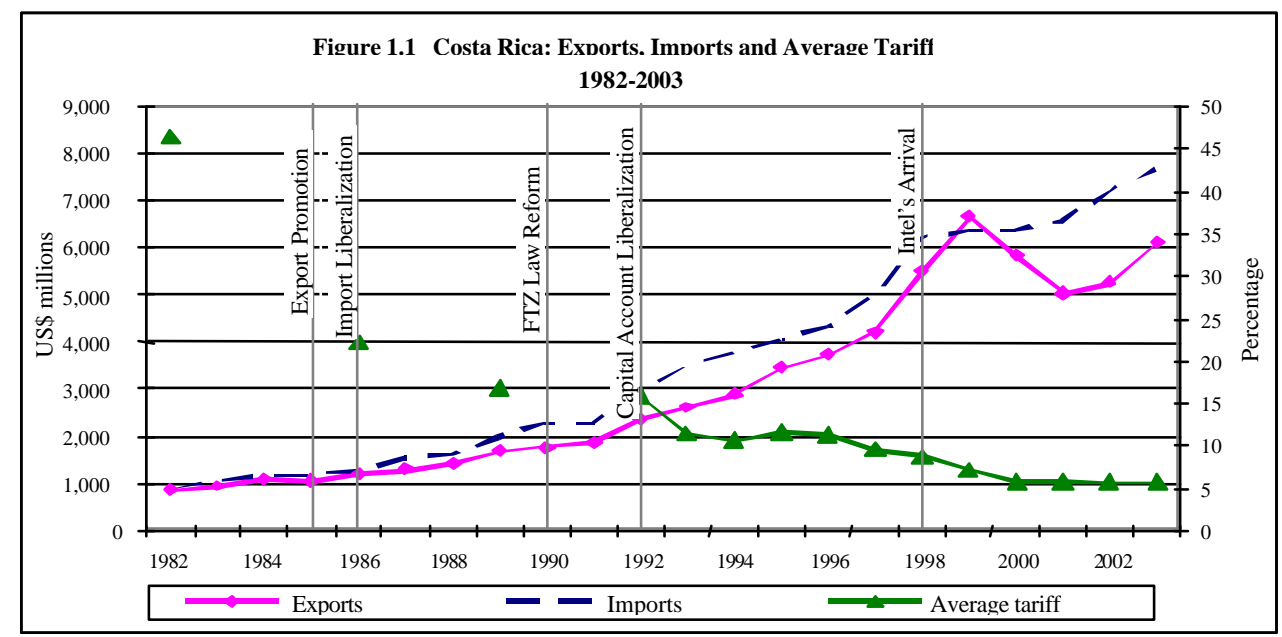

Source: Prepared by the authors based on figures from Banco Central de Costa Rica.

It is worth noting that in 1984, along with economic liberalization, Costa Rica's export products began enjoying free access to the US market (zero tariffs on almost all manufactured and agricultural products), thanks to the Caribbean Basin Initiative (CBI). Not surprisingly, therefore, the US market has grown in terms of its relative importance

\footnotetext{
2 Applying Lerner's theorem (1936), Monge (1994) estimated that 0.66 out of each percentage point of protection granted to Costa Rica's manufacturing sector during the import-substitution period was transferred as an implicit tax to the country's export efforts.

3 See Corrales and Monge (1990), Lizano (1992), Céspedes and Jiménez (1997), and Monge and Lizano (1997).
} 
as a major destination for Costa Rica's exports, from $26 \%$ in 1982 to $38 \%$ in 1992 and $46.5 \%$ in 2003 (Figure 1.2). This was in part the result of a significant increase in foreign investment inflows, with the establishment of companies such as Componentes Intel in 1998.

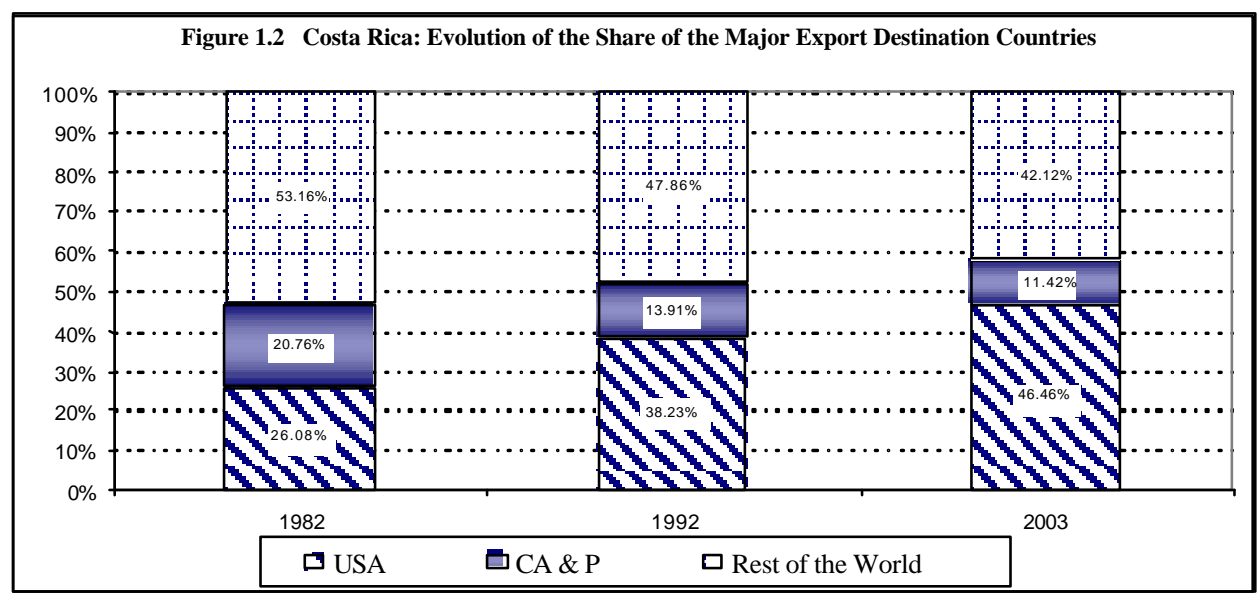

Source: Prepared by the authors based on figures from PROCOMER.

The good export performance and the higher foreign direct investment (FDI) inflows, together with an adequate foreign exchange policy, have resulted in a relatively satisfactory improvements in the balance of payments' trade account, since although at present the current account deficit is higher in absolute terms, this deficit has tended to decrease relative to the size of the economy (Figure 1.3).

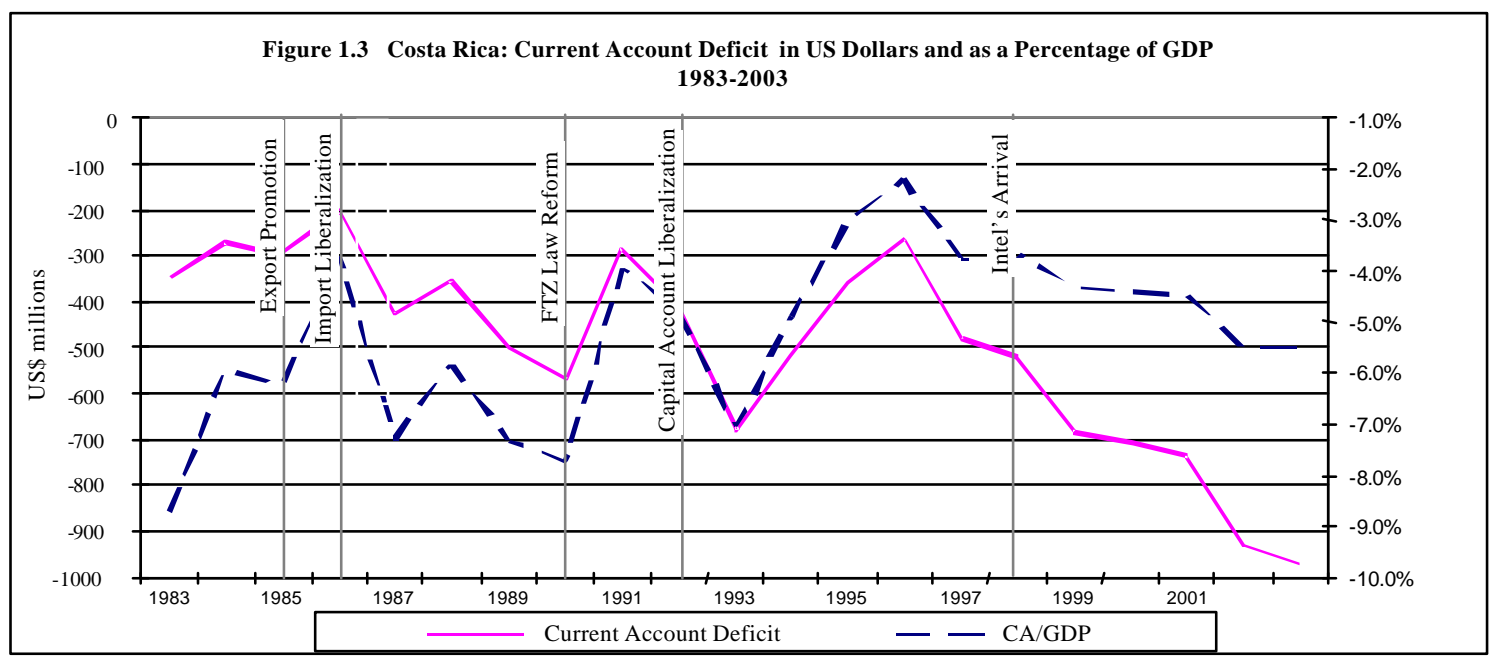

Source: Prepared by the authors based on figures from Banco Central de Costa Rica.

The latter is a very important result, in view of the fact that the opponents of the liberalization process forecast that the trade balance would be wrecked as a consequence of import liberalization. Thus, the performance of Costa Rica's economy during the last two decades demonstrates the profound economic understanding of the designers of the reform, as they took into account the general and not merely the partial equilibrium effects when designing and implementing the process of economic liberalization. In fact, 
because of the prudent management of the fiscal, monetary and exchange policies, Costa Rica has been able to guarantee a neutral exchange rate (as measured by the real effective exchange rate index - REER) and relatively low inflation levels to its export sector (Figure 1.4).

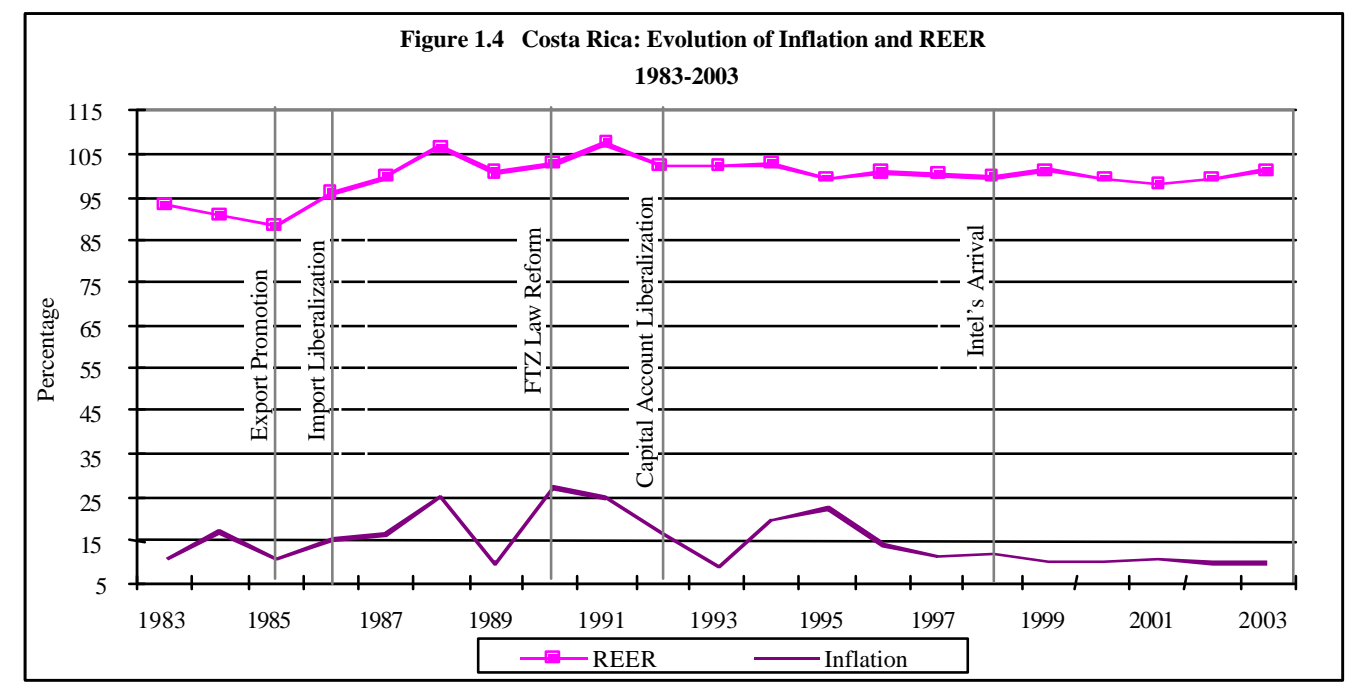

Source: Prepared by the authors based on figures from Banco Central de Costa Rica.

Attempts have been made to minimize the significance of the response of Costa Rica's business community to the liberalization of the economy, by pointing out that the increase in Costa Rica's exports is mainly associated with the foreign sales of the multinational companies under the free trade zone regime. The truth is that, although multinational companies are currently an important source of wealth for the country-by generating new and better employment sources and technology transfer to domestic businesses, among other positive effects - the results shown in the previous figures underline the importance of the liberalization in achieving a better allocation of the resources of Costa Rica's economy, along with the entry of multinational companies since the second half of the 1990s. ${ }^{4}$

The sustained growth of FDI inflows into Costa Rica is another positive outcome of economic liberalization, as it is an evidence of the foreign investors' confidence in the new development model (Figure 1.5). Such investments have become not only an important source of jobs, but also a major destination market for products manufactured by domestic micro, small and medium-sized enterprises, turning them into indirect exporters (Monge et al., 2005).

\footnotetext{
${ }^{4}$ For a detailed discussion on the positive effects of the companies under the protection of Costa Rica's free trade zones, see Monge et al. (2004).
} 


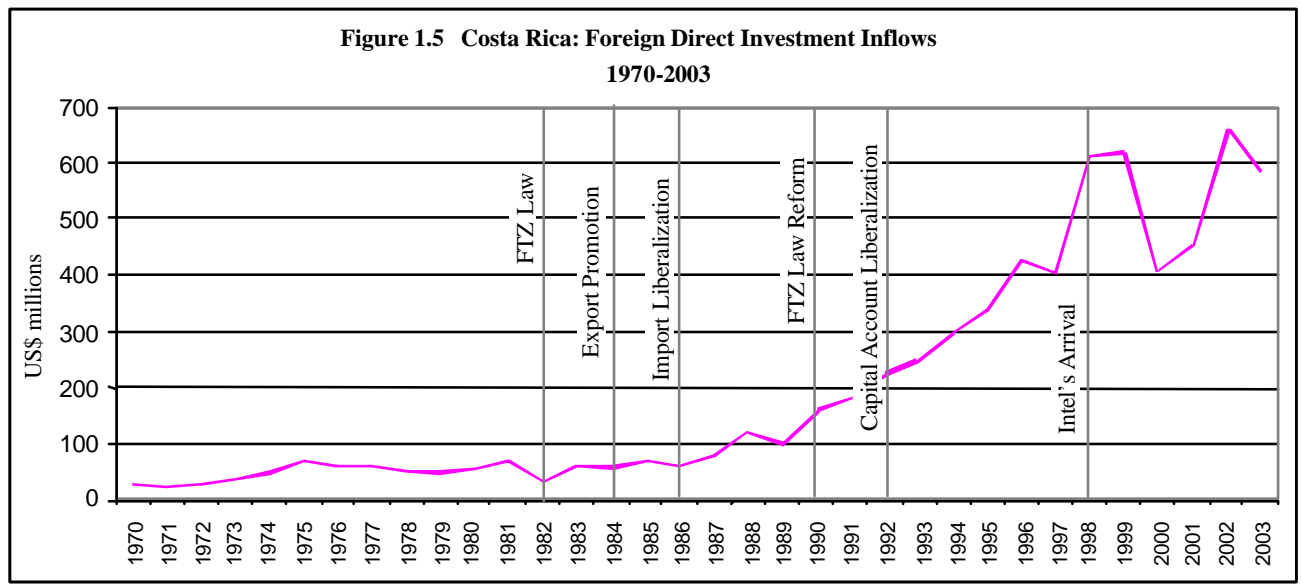

Source: Prepared by the authors based on figures from Banco Central de Costa Rica.

Complementing the previous paragraphs, it should be pointed out that, thanks to the liberalization process, Costa Rica's economy has succeeded in reducing its extremely high dependence on traditional activities, such as coffee, bananas, sugar and beef, for the generation of foreign exchange earnings. In fact, as shown in Figure 1.6, owing to the economic liberalization exports of non-traditional products have substantially increased their relative importance in total exports, from $38.6 \%$ in 1982 to $64.9 \%$ in 1992 and $87 \%$ in 2003. Such increased diversification of exports currently provides Costa Rica with greater economic stability and a more stable source of foreign exchange, thus avoiding the recurrent problems of the past, when a good economic performance was dependent on whether the price of coffee increased as a consequence of external impacts (for example, sleet in Brazil). Moreover, we might wonder about what the condition of Costa Rica's economy would be, given the current crisis of the coffee sector, if this major diversification of exports had not taken place.

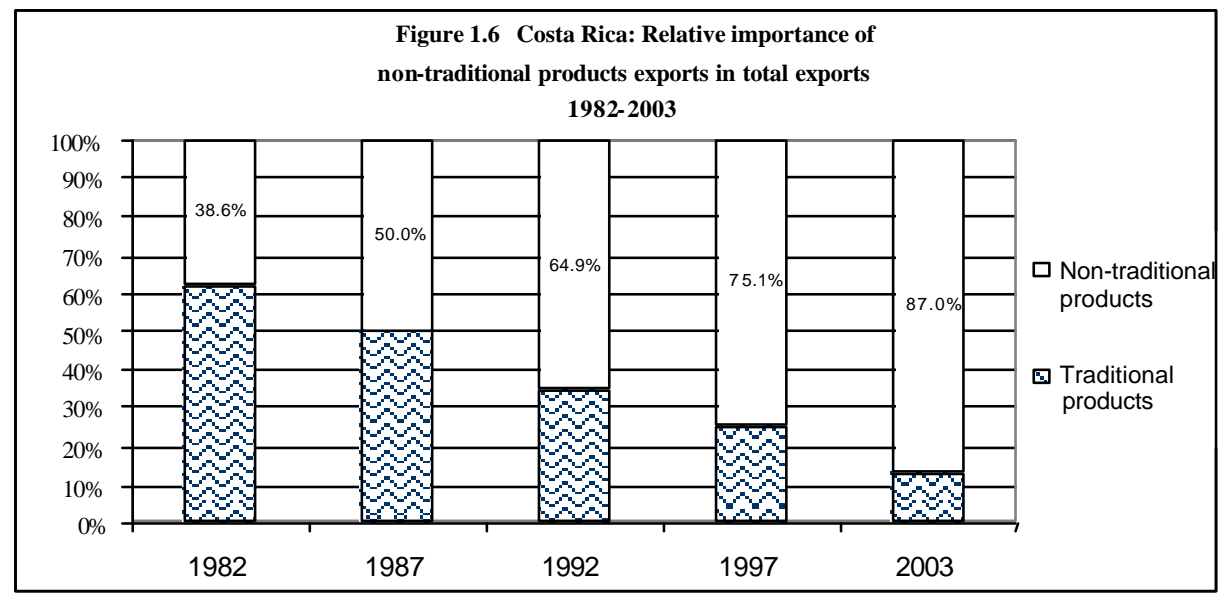

Source: Prepared by the authors based on figures from Banco Central de Costa Rica.

It is also worth pointing out that the sustained growth of Costa Rica's exports has been associated to an increase in the number of exporting firms, as well as to an important participation of micro, small and medium-sized enterprises in this process. In fact, as 
shown in Figure 1.7, it is estimated that out of the over 1,700 currently exporting companies, $15 \%$ are microbusinesses and $58 \%$ are small and medium-sized enterprises (SMEs). ${ }^{5}$ Equally important is the increasing number of products exported by Costa Rica, which amounted to 3,565 in the year 2003, according to official data from the Promotora de Comercio Exterior de Costa Rica (Costa Rica's Foreign Trade Promotion Bureau).

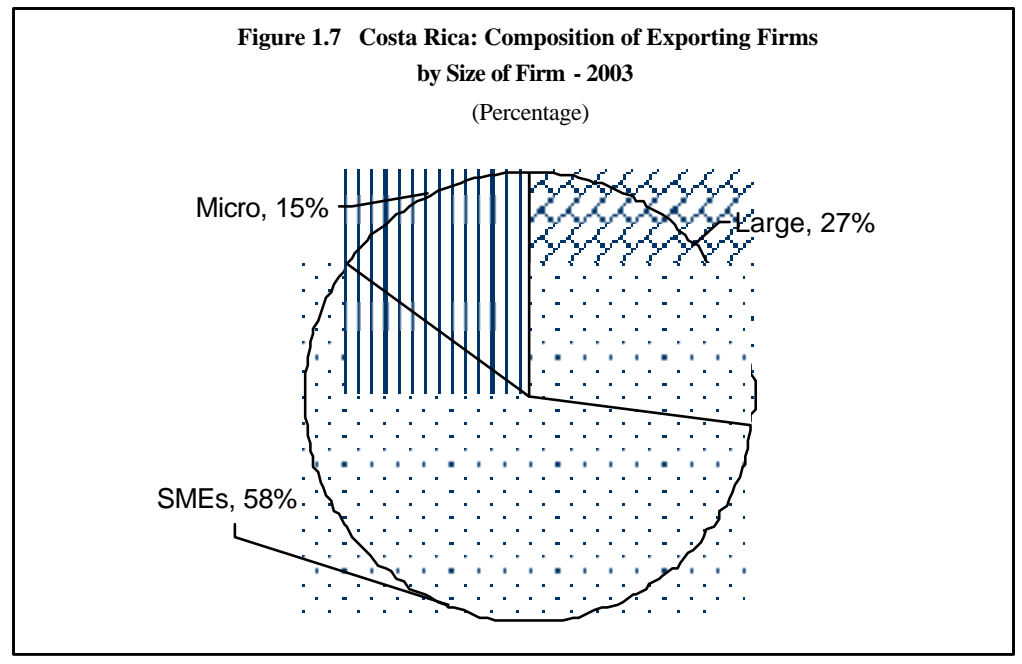

Source: Prepared by the authors based on figures from PROCOMER.

Finally, it should be noted that Costa Rica's economic performance, linked to trade liberalization, has achieved three more major successes. First, it facilitated a reduction of the high levels of unemployment and underemployment that resulted from the foreign debt crisis of the late 1970s and early 1980s; second, it has made it possible to absorb a large increase in the supply of unskilled workers that was the consequence of the important migration flows of people from Central America, mainly Nicaragua, that occurred in the last few years; and finally, it has managed to bring down the poverty level from $29 \%$ in 1987 (a year after the liberalization process began) to $18.5 \%$ in 2003 (Figure $1.8){ }^{6}$

In addition to the positive outcomes of the economic liberalization model regarding trade flows, foreign investment, employment and poverty, it should be noted that although Costa Rica's income distribution did not improve over the liberalization period, it did not worsen. In fact, according to the family distribution of income based on the per capita income of Costa Rica's households, Gini's coefficient has not changed much between the years 1987 (0.401) and 2003 (0.425), with an average of 0.395 for the period and a coefficient of variation of only $4.9 \%$. $^{7}$

\footnotetext{
5 According to the records of Costa Rica's Foreign Trade Ministry, the country had 1744 exporting businesses in 2003 .

${ }^{6}$ In fact, according to figures from the last population census (2000), immigrants make up one fourth of Costa Rica's population.

${ }^{7}$ Due to a change in the methodology for conducting the household survey in 1987, figures from previous years are not comparable. For that reason, the income distribution and poverty figures used in this paper are from 1987. However, for the purposes of our analysis, this situation is not a serious restriction, since Costa Rica's liberalization period began in 1986.
} 


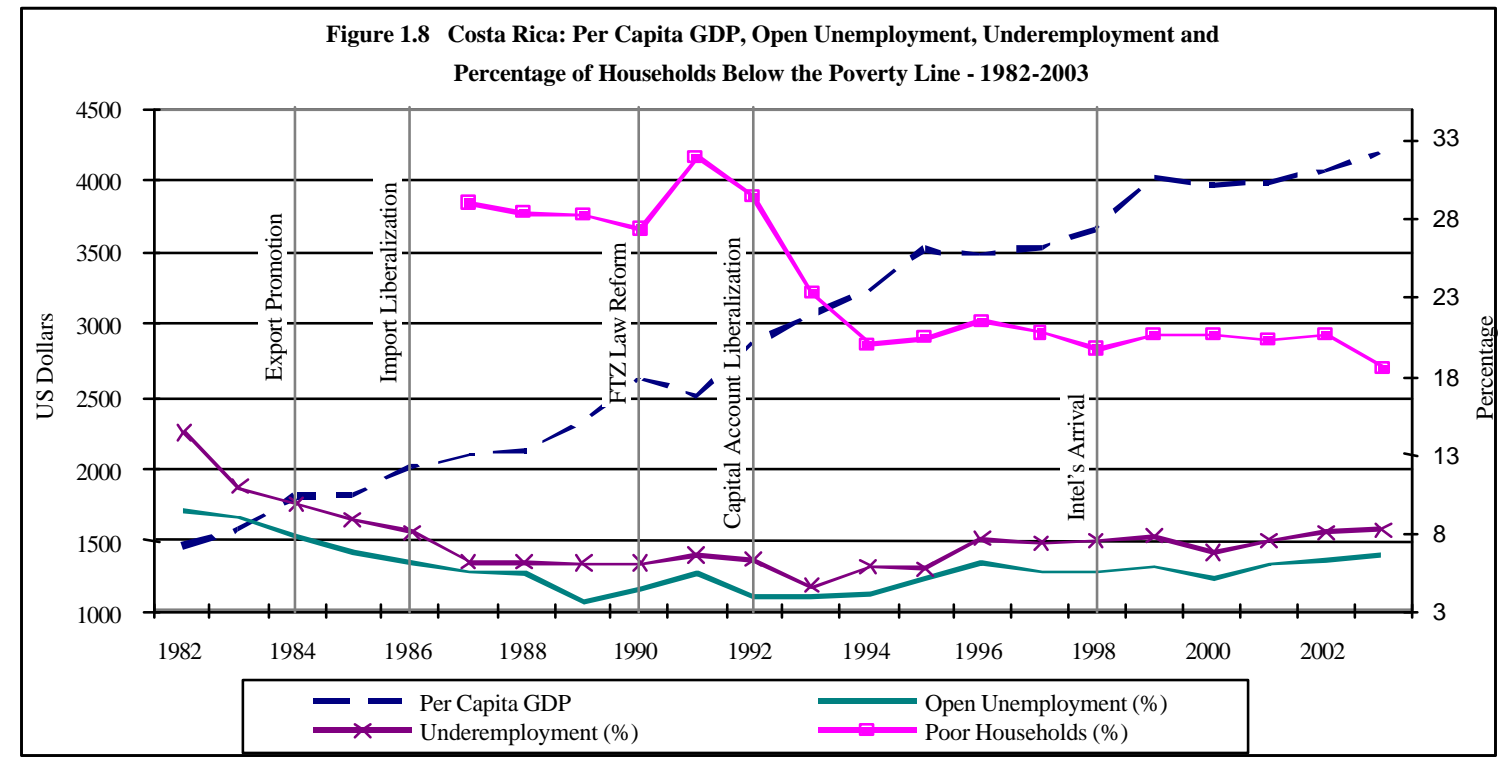

Source: Prepared by the authors based on figures from Banco Central de Costa Rica.

Costa Rica's production behavior, in per capita terms, indicates that the new development model has provided greater robustness to the country's economy, since it was not seriously affected by significant external events such as the Tequila crisis (1995), the Asian crisis (1999), the Argentine crisis (2001) and the most recent recession in the developed economies, notably the United States (2002).

Summarizing, Costa Rica has managed to attain a positive economic performance over the last two decades, as a result of changing the development model from one based on import substitution to another of economic liberalization. Indeed, and as cited by numerous scholars and international organizations, Costa Rica is presented as an example of successful reform, albeit incomplete, in which no crisis episodes have occurred vis-àvis the greater degree of integration into world market (Figure 1.9), while there have been significant improvements in the fight against poverty. 


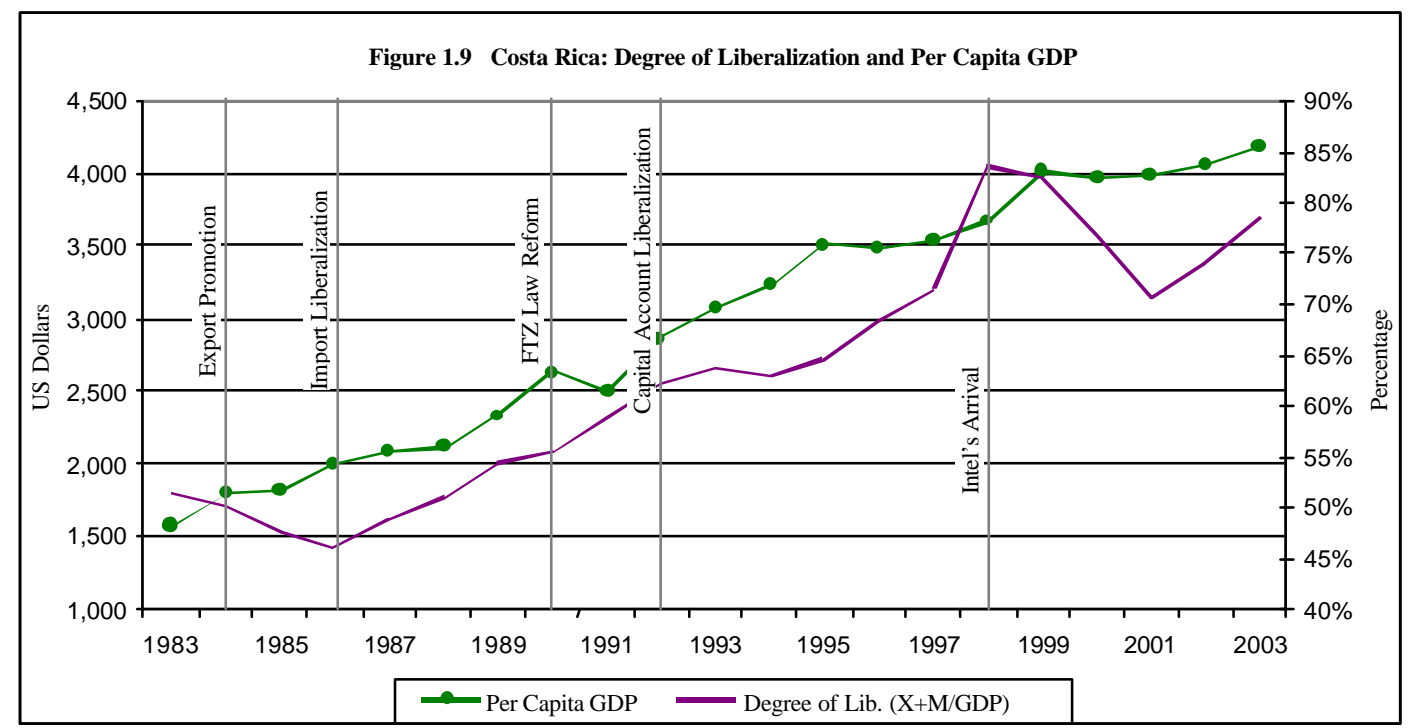

Source: Prepared by the authors based on figures from Banco Central de Costa Rica. 


\section{SECTION II}

\section{Legal Framework}


Although Costa Rica does not have domestic legislation regulating safeguards or antidumping, the Uruguay Round Anti-Dumping and Safeguard Agreements are the cornerstone of the legal framework that determines the parameters to identify and penalize such practices in Costa Rica's imports from any WTO member country. Consequently, these agreements regulate dumping practices and the application of safeguard measures within the context of multilateral trade.

Supplementing said international agreements-which Costa Rica adopted with the enactment of Law 7475 dated April 15, 1994 - the country has established bilateral rules to regulate dumping practices and the application of safeguards in the various free trade agreements it has signed and approved to date, specifically with Central America, Mexico, Chile, the Dominican Republic and Canada. ${ }^{8}$

The purpose of this section is to present a summary of the basic rules established in the above-mentioned agreements in order to have a clear perspective of the way in which the safeguards and dumping issues are regulated at both the multilateral and bilateral levels.

\section{2.a Anti-Dumping Measures}

\section{2.a.1 Anti-Dumping Measures at the Multilateral Level}

As mentioned above, the identification and penalization of dumping practices at the multilateral level is regulated by the Anti-Dumping Agreement of the Uruguay Round, signed and approved by Costa Rica in 1994.

For the purposes of the Agreement, a product is considered as being dumped if it is being sold into another country's market at a price that is less than the normal value for that or a like product (close substitute). The key to determine dumping in this Uruguay Round Agreement lies in the definition of "normal value", since this is the parameter against which the price at which the product is being imported is compared. The normal value is defined in three alternative and mutually exclusive ways, which shall be applied in the following order according to the circumstances:

a- If the product under consideration is being sold in the exporting country's domestic market, then the normal value is the selling price in said market.

b- If the product is not sold in the exporting country' domestic market, then the normal value is the price at which said product (or the like product, as the case may be, i.e. a product which is either identical in all respects or has characteristics

\footnotetext{
${ }^{8}$ In spite of the fact that the Free Trade Agreement with the United States (CAFTA) has already been signed by the executive branches of both parties, it is still pending approval by Congress in both countries. Consequently, the provisions on anti-dumping and safeguards contained in said Agreement are not yet part of the legal framework governing these matters in Costa Rica. For that reason, they have not been included in this section of the investigation. To review the provisions of CAFTA on those areas, see the text of the Agreement at www.comex.go.cr.
} 
closely resembling those of the product under consideration) is sold in a third country, provided that said price is representative.

c- If the product is neither sold in the exporting country's domestic market nor in third markets-or when a special market situation or the low volume of sales in the domestic market of the exporting country does not make an appropriate comparison feasible - the normal value shall be determined as the sum of the per unit cost of production at the country of origin and a reasonable amount for administrative, selling and general costs and for profit.

Likewise, the Agreement provides that when the export price is unreliable because of association or compensatory arrangement between the exporter and the importer or a third party, the export price may be constructed on the basis of the price at which the imported products are first resold to an independent buyer.

Another relevant aspect is that the price comparison must be fair, in the sense that it must be made at the same level of trade, preferably at the ex-factory level and in respect of sales made at as nearly as possible on the same date.

Once determined whether there is dumping or not and the amount thereof, the next step is a determination of injury to domestic production. In this respect, the Agreement provides that, for a determination of injury ${ }^{9}$ to domestic producers, the investigating authorities shall examine both the volume of the dumped imports and their effect on the prices in the domestic market for like products, in addition to the consequent impact of these imports on domestic producers of such products.

Two important elements in the Anti-Dumping Agreement of the Uruguay Round are the possibility of imposing provisional measures and the price undertakings. Provisional measures are countervailing duties that are applied on a strictly transitory basis and for a defined period of time. Such measures shall not be applied sooner than 60 days from the date of initiation of the investigation, shall be limited to a period not exceeding six months and their amount shall not be greater that the provisionally estimated margin of dumping. Thus, it is clear that imposing a provisional measure requires that a preliminary determination have been made of the existence of dumping and its consequent injury to a domestic industry, and also that it be considered necessary to establish such measure to prevent the persistence of injury during the investigation.

Price undertakings, on the other hand, are voluntary agreements whereby the exporter of the product being dumped undertakes to revise its prices or to cease exports to the area in question at dumped prices so that the authorities are satisfied that the injurious effect of the dumping is eliminated. Price increases in such undertakings need not be equivalent to the estimated margin of dumping, but simply sufficient to remove the injury to the domestic industry. Evidently, the acceptance of this type of undertaking requires that, as in the case of provisional measures, a preliminary determination of the existence of dumping, its amount and the injury it causes to domestic production has been made.

\footnotetext{
9 The term "injury" means material injury or threat of material injury to a domestic industry or material retardation of the establishment of such an industry.
} 
When the investigating authorities complete the investigation by determining the existence of dumping and of injury to domestic production - and in the absence of a price undertaking by the exporter-it shall proceed to impose a final measure, i.e. a countervailing duty, with the purpose of offsetting the injury caused by the artificial manipulation of the price by the exporter with predatory purposes in the domestic market of the importing country. The Agreement is clear in that such measure will remain in force only while it is strictly necessary and at the most for five years as from the date of its imposition, unless the investigating authorities determine in a review that it is essential to maintain it because, should they terminate it, the dumping and injury would continue or recur.

\section{2.a.2 Anti-Dumping Measures in the Central American Common Market}

As regards bilateral trade with Central America, the application of anti-dumping measures is properly regulated by the Central American Regulations on Unfair Trade Practices, adopted on December 12, 1995 by the Central American Economic Council in the framework of the treaty establishing the Central American Common Market and as a response to the commitments made during the Uruguay Round by each of the countries in the region within the context of the establishment of the WTO.

Before its accession to the GATT, Costa Rica had the Industrial Protection and Development Act (Ley de Protección y Desarrollo Industrial), covering dumping in Articles 10, 11 and 12. ${ }^{10}$ However, it was never enforced, given the high tariffs that existed and the limited opening of the economy to foreign competition. Furthermore, there was no specific institutional framework for the enforcement of said legislation.

The Regulations establish an Investigating Authority (IA), which shall be the DirectorateGeneral of the Ministry of Economy, Industry and Trade (MEIC, in Spanish) or, as the case may be, the Directorate responsible for regional integration affairs in each country in the Isthmus or the technical unit in charge of the investigation of unfair trade practices. However, in the case of a regional procedure (i.e. a joint complaint of all the countries in the region against a third one), the Secretariat for Central American Economic Integration (Secretaría de Integración Económica Centroamericana - SIECA) will be responsible for the investigation.

The IA shall investigate, analyze and evaluate the alleged unfair trade practices and decide whether is appropriate to recommend the application of duties or anti-dumping measures, be they provisional or final. Applications for initiating an investigation may be made by the representatives of the domestic industry responsible for the product adversely affected by the imports, but can also be the result of an administrative initiative, as provided under WTO rules.

${ }^{10}$ The Industrial Protection and Development Act, passed on May 18, 1960, authorized the Ministry of Econmy, Industry and Trade (MEIC, in Spanish) to take the necessary measures to counteract unfair trade practices. 
In case an application for investigation is accepted by the IA, it shall notify the government of the country of origin or export of the product to be investigated, and shall afford it an opportunity to hold consultations aimed at clarifying the facts raised in the application.

Investigations must be completed within 12 months of date of their initiation and only under exceptional circumstances may they be extended for a further period of 6 months. However, within 60 days the IA shall issue an affirmative or negative preliminary determination on the case.

Figure 1 summarizes the process of a dumping complaint investigation in Costa Rica on imports originating in Central America. 


\section{Figure 1: Stages in the Process of a Dumping Complaint in Costa Rica, pursuant to the Central American Regulations}

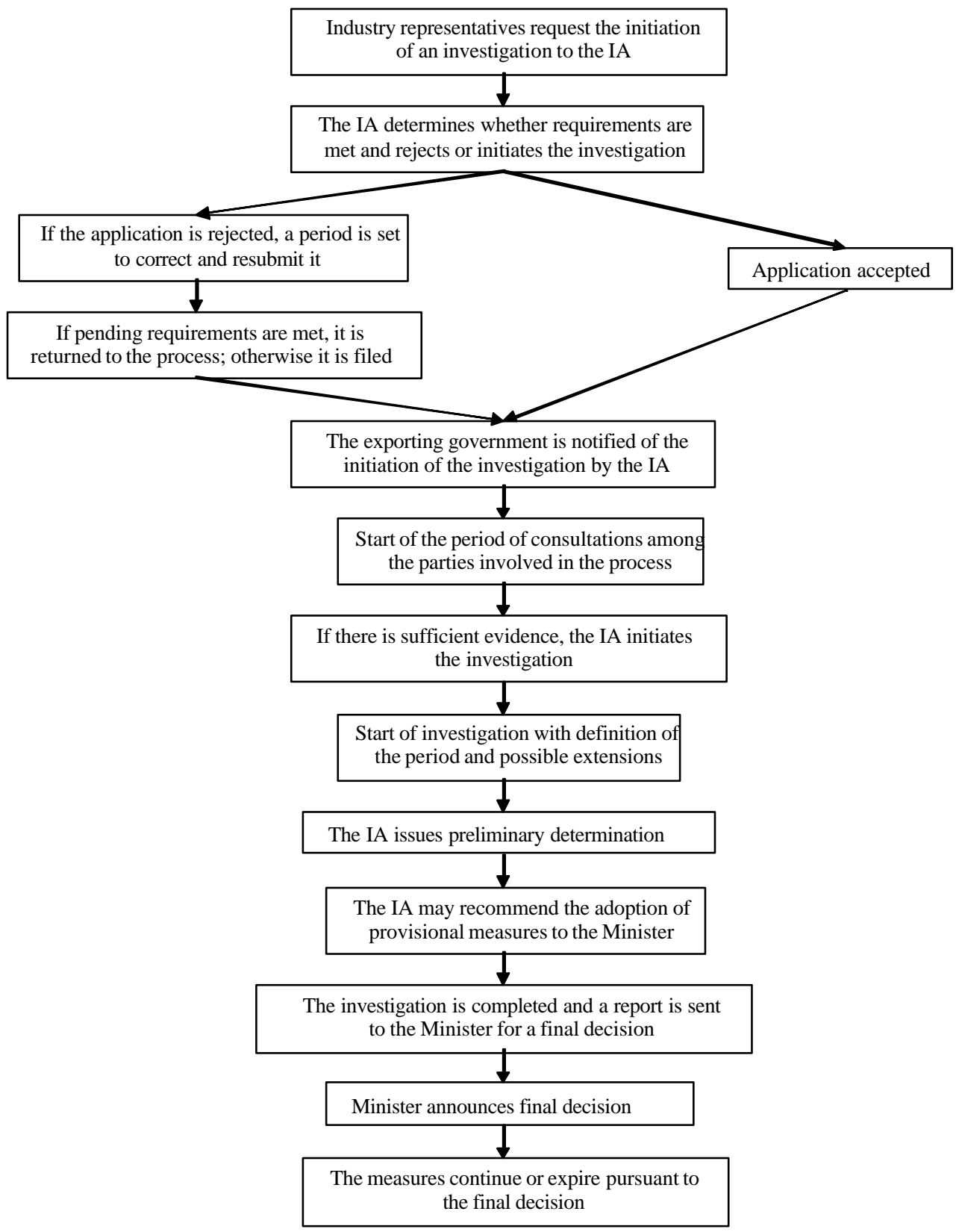

Note: The Minister has the power to terminate the process at any stage.

The IA is the Investigating Authority, an agency reporting to the Ministry of Economy, Industry and Trade. Source: Prepared by the authors on the basis of the Central American Regulations on Unfair Trade Practices. 


\section{2.a.3 Anti-Dumping in the Free Trade Agreement with Mexico}

In the case of the Free Trade Agreement (FTA) with Mexico, Chapter VIII defines the guidelines relating to the application of anti-dumping measures in the form of "countervailing quotas" and not duties, as is the typical case. However, it is worth mentioning that, according to the provisions of Chapter VIII, countervailing quotas can be used not only to offset dumping practices but also export subsidies.

As regards the conditions required to impose an anti-dumping measure, Chapter VII of the FTA with Mexico refers to the GATT provisions, i.e. the Anti-Dumping Agreement of the Uruguay Round. The only particular specifications made in this chapter have to do with the conditions required for the accumulation and establishment of "regional injury", as well as some aspects of the process related to resolutions, notifications, retroactive application, hearings, review and elimination of final measures.

\section{2.a.4 Treatment of Dumping in other Free Trade Agreements}

On the other hand, Chapter VII of the free trade agreements with Chile, the Dominican Republic and Canada contains provisions regarding the application of anti-dumping measures, setting forth that the parties can establish the application of countervailing duties in response to dumping practices, pursuant to the Uruguay Round Agreement in question.

However, the FTA with Canada goes a bit further by providing for the interest of the parties to promote improvements and clarifications of the GATT 1994 provisions, as well as the desire to establish a procedure at the domestic level that incorporates broader issues of public interest. Furthermore, it sets forth the possibility of applying countervailing duties less than the margin of dumping and recommends a transparent and predictable method for the imposition of such duties, so that the final determinations of duties may be more easily reviewed.

\section{2.b. Safeguard Measures}

\section{2.b.1 Safeguard Measures at the Multilateral Level}

Safeguard measures at the multilateral level are governed by the Agreement on Safeguards of the Uruguay Round, signed and adopted by Costa Rica in $1994 .{ }^{11}$

The basic condition set by said Agreement for the imposition of safeguard measures is that the imports of a certain product is being imported in such increased quantities,

\footnotetext{
${ }^{11}$ In this Agreement, safeguard measures are also called "Emergency Action on Imports of Particular Products."
} 
absolute or relative to domestic production, that they cause or threaten to cause serious injury to the domestic industry that produces like or directly competitive products. ${ }^{12}$

The key element for the application of safeguard measures is the determination of injury. According to the Agreement in question, "serious injury" is understood to mean a significant overall impairment in the position of a domestic industry. Furthermore, it is clearly established that the "threat of serious injury" must necessarily be based on concrete facts and not merely on allegation, conjecture or remote possibility.

To determine injury, the investigating authorities have the express obligation to evaluate all relevant factors of an objective and quantifiable nature, since the imposition of a safeguard measure will not be warranted unless the investigation demonstrates the existence of the causal link between increased imports and serious injury to the domestic industry concerned.

The measure to be applied may be a duty or a quantitative restriction (quota), in which case the amount of the measure shall not be less than the average of the product's imports over the 3 years prior to the beginning of the investigation. It is also established that it is possible to apply provisional safeguard measures provided that the existence of critical circumstances where any delay would cause injury to domestic production that would be difficult to repair is confirmed.

The duration of such provisional measures shall not exceed 200 days, and they may only take the form of tariff increases to be promptly refunded to importers should the investigation conclude that there is no evidence of a causal link between increased imports and serious injury to the domestic industry. Additionally, the duration of any such provisional measure shall be discounted from the initial duration of a final safeguard measure, should it be imposed as a result of the investigation. ${ }^{13}$

The Agreement provides that countries will be able to apply final safeguard measures only for such a period of time as may be necessary to prevent or remedy serious injury and facilitate adjustment. However, the duration of said period is limited to a maximum of 4 years, at the conclusion of which it is possible to grant an extension provided that it is demonstrated that the measure continues to be necessary to prevent or remedy the injury or to complete the period of adjustment of the domestic industry. ${ }^{14}$ The extensions of a safeguard are limited, however, since the agreement provides that the total period of application of a final safeguard measure, including the period of initial application and any extension thereof, shall not exceed 8 years.

\footnotetext{
12 The Agreement defines "domestic industry" as the producers as a whole-operating within the territory of a WTO Member - of the like products of or the products competing directly with the good under investigation.

${ }^{13}$ It should be borne in mind that the term "final measure" refers to the definitive nature of the final resolution of the investigating authorities and not to an undefined duration of the measure in time.

${ }_{14}$ Although not explicitly defined in the Agreement, the term "adjustment" seems to be understood as a process of productive reconversion in which resources of the affected activity are mobilized towards other activities not susceptible of being injured by imports.
} 
Additionally, a product to which a safeguard measure has been previously applied shall not be the subject to a new measure until a period equal to that during which such measure had been previously applied has elapsed, provided that the period of nonapplication is at least two years.

One last relevant aspect of the Uruguay Round Safeguards Agreement is that it forbids the application of any such measures against imports of a product originating in a WTO developing country Member when such imports do not exceed 3\% of the total imports of that product in the importing Member allegedly affected by the increased in imports.

\section{2.b.2 Safeguards in the Central American Common Market}

In the Central American region, the legislation that is applied by the country regarding safeguard measures is governed by the Central American Regulations on Safeguard Measures, adopted on May 22, 1996 by the Central American Economic Council in the Tegucigalpa Protocol with the purpose of bringing the regional rules in line with the agreements adopted in the framework of the Uruguay Round.

In general, the investigation procedures and timeframes are similar to those applied in the case of anti-dumping measures. The investigation process can be initiated at the request of a party or, exceptionally, by administrative initiative. The technical study shall be completed within 6 months, except under special circumstances, where it may be extended to a maximum of 12 months.

It is possible to apply provisional measures, but they shall be guaranteed by bonds, to be promptly refunded if the subsequent investigation does not determine that increased imports have caused or threatened to cause serious injury to a domestic industry. Furthermore, before the adoption of any provisional measure, the Member State shall notify the WTO's Safeguards Committee. Once a provisional measure is imposed, the authorities of the Member State shall hold consultations with WTO Member countries that have a particular interest in the measure.

\section{2.b.3 Safeguards in the Free Trade Agreement with Mexico}

In the case of the Free Trade Agreement with Mexico, the application of safeguard measures is authorized both at the bilateral (against imports originating in Mexico) and global (against imports from Mexico and other countries) levels.

Safeguards of a bilateral nature shall be applied before 24 months have elapsed from the date the tariff on the product in question reached $0 \%$. Additionally, it is established that the only measures that may be adopted are tariff measures.

An interesting aspect in which the rules on bilateral safeguards contained in the FTA with Mexico deviate from the WTO bilateral rules concerns the period of application of the 
safeguard. In fact, it may be applied only once, for a period of time that shall not exceed one year and with a single possibility of extension for a like period. Moreover, the level of the measure shall not be higher than the tariff in force for third countries or than the tariff that was in force before the effective date of the tariff reduction defined in the Treaty.

Another distinctive element in the application of safeguards under the FTA with Mexico is the fact that the party imposing the safeguard measure must offer the affected party a compensation mutually agreed upon during the consultations that shall consist of additional tariff concessions (reductions), the positive effects of which on the trade of the party causing the injury are equal to the impact of the safeguard measure.

In the case of global safeguards, their imposition on imports of a specific product originating in Mexico only applies when:

- $\quad$ They are part of the exports of the main supplying countries and these represent no less than $80 \%$ of the total imports by the affected country of the product in question.

- The rate of increase of the imports from Mexico of the product concerned during the year when their injury increase occurred is slightly lower, equal or higher than the rate of increase of the imports of the same product originating in any country during the same period.

The procedure for the application of global safeguards in the FTA with Mexico covers the issues relating to investigation, notification and consultations that were mentioned in connection with bilateral safeguards, but not those linked to the tariff concessions for the party affected by the safeguard measure.

\section{2.b.4 Safeguards in the Free Trade Agreement with Chile}

As regards the FTA with Chile, the application of safeguard measures is duly outlined in Chapter VI, both in the case of bilateral (i.e. only against imports from Chile) and global (against imports originating in a group of countries including Chile) measures.

The period during which the parties may impose safeguard measures and keep them in force (for the purposes of the Treaty, the "transition period") is restricted to the time required to reduce the tariff on the product plus an additional two-year period as from the date on which the product becomes completely tariff-free, which is identical to what is provided for in the FTA with Mexico.

In the FTA with Chile, the only applicable safeguards are tariff measures, and their imposition may take the form of either a suspension of the tariff reduction agreed under 
the Treaty or an increase of the tariff rate to a level that under no circumstances may exceed the most-favored-nation (MFN) tariff rate bound in the WTO. ${ }^{15}$

An element in common with the Costa Rica-Mexico FTA regarding the application of bilateral safeguards is the obligation to offer, in exchange for the imposition of a safeguard measure, a compensation (tariff reduction) with effects equivalent to those of the safeguard. What is new in the FTA with Chile is that this obligation to offer a compensation to the other party is extensive to global safeguards.

However, the FTA with Chile clearly departs from the FTA with Mexico as regards to the period of application of bilateral safeguards, since it is established that such safeguards shall have a maximum duration of 3 years, which may be extended for a period of one consecutive year. Additionally, during the transition period a bilateral safeguard shall be applied to a product no more than two times, the second application only being possible if a period equivalent to at least half the time of the period during which the measure was first applied has elapsed.

Another novelty in the FTA with Chile concerning the application of bilateral safeguard measures is the gradual elimination of the measures. Equally new is the obligation to exclude the other party from the imposition of the global safeguard measures in which it is involved. Thus, when imports from Chile have a substantial share in the total imports of the product in question and significantly contribute to the serious injury caused to domestic production, Costa Rica will have the obligation to exclude Chile from the application of the corresponding global safeguard measure.

As in the case of the application of bilateral safeguards, the Agreement provides for a procedure for global safeguards, in which elements such as consultations, notifications, hearings and the provision of objective evidence to the other party guarantee the transparency of the process.

\section{2.b.5 Safeguards in the Free Trade Agreement with the Dominican Republic}

In the case of the FTA with the Dominican Republic, an innovation introduced in the treatment of safeguards is the definition of "domestic industry", since it is established that the domestic producers of the like products or the products that directly compete with the imported product subject to the safeguard measure must account for at least $25 \%$ of the total domestic production of that type of product.

Regarding the duration of the transition period and the periods of application of the measure, the treatment is identical to that of the FTA with Mexico.

A rather peculiar aspect in the treatment of bilateral safeguards in the FTA with the Dominican Republic is the fact that the compensations in the form of tariff reductions

\footnotetext{
15 The lowest of the following MFN tariffs will apply: the one in force at the time the measure is adopted
} and that in force on the day prior to the effective date of the Treaty. 
offered in exchange for the imposition of safeguards-which are mandatory in the treaties with Mexico and Chile-are optional in this case and are left to the discretion of the party applying the safeguard measure. In case of failure to agree on the compensation to be offered in exchange for the safeguard (tariff reduction on other products), the requesting party shall be able to impose it unilaterally while the party subject to the safeguard measure may unilaterally impose the compensation it deems relevant.

\section{2.b.6 Safeguards in the Free Trade Agreement with Canada}

Finally, as to the Free Trade Agreement with Canada, the treatment of safeguards is much briefer, inasmuch as it only deals with the application of bilateral measures (i.e. only against imports originating in Canada).

Thus, a transition period is established, the duration of which is restricted to the time scheduled for the reduction of the tariff on a product, while the maximum duration of safeguard measures is limited to 3 years without the possibility of an extension; the measure may be applied only a second time provided that after the expiration of the first application period no less than half of its duration has elapsed. During the second imposition of the measure, the tariff shall not be higher than that applied the first time the safeguard was in force, while during this second application it is mandatory to establish a time schedule for a gradual tariff reduction so that, at the date of final expiration of the measure, the tariff will remain at the level specified for the product in question in the tariff reduction schedule under the Treaty.

It is also provided that no safeguards shall be applicable after the expiration of the transition period-except when accepted by the other party-and that the party imposing a safeguard has the obligation to negotiate and agree on the respective compensation with the other party, the party affected by the safeguard having the possibility of adopting a unilateral compensation should the parties fail to reach an agreement. 


\section{SECTION III}

\section{Institutional Framework}


As indicated in the previous section, the application of anti-dumping and safeguard measures in Costa Rica relies on the relevant agreements of the Uruguay Round at the multilateral level, and on the various free trade agreements signed by the country at the bilateral trade level.

Within this context, by Official Communication DM-822-95 dated September 4, 1995 the Ministry of National Planning and Economic Policy (MIDEPLAN, in Spanish) authorized the creation of the Office of Unfair Trade Practices and Safeguard Measures, reporting to the Ministry of Economy, Industry and Trade (MEIC, in Spanish), which would be responsible for investigating, analyzing and evaluating cases involving unfair trade practices and safeguard measures, as well as advising the Minister of the MEIC on the application of anti-dumping duties, safeguards and countervailing measures.

The Office was operational between 1995 and 2000, when MIDEPLAN issued Official Communication DM-23-00, whereby, due to the restructuring of the MEIC, the functions of the Office were transferred to the Legal Affairs Unit (UAJ, in Spanish) of said Ministry. Pursuant to this Official Communication, on December 6, 2000 the MEIC published a decree to that effect, although it had argued that transferring the responsibilities of the Office to the UAJ generated an inconvenient combination of functions.

Based on interviews and conversations held with government officials concerned with the subject and with advisors of domestic companies involved in investigativeprocesses, it was concluded that, among the major restrictions experienced by the MEIC's Office during its operation, the following may be mentioned:

- Financial restrictions.

- Staff limitations and lack of continuity.

- Shortage of staff specializing in economy and international trade matters.

- Lack of training and updating of specialized knowledge on the subject.

- Processes tended to become delayed, partly due to the reluctance of the applicant companies themselves to provide information, but also as a consequence of the above-mentioned staff limitations and the lack of an adequate budget.

Even though the Office operated under financial and staff constraints ever since it was set up, Mr. Douglas Alvarado, currently responsible for processing complaints on the matters in question, was of the opinion that the authorities justified the disbanding of the Office based on the fact that only a fewapplications for investigation were being received.

The Legal Affairs Unit, for its part, continues following the same procedures prescribed in the relevant legislation, but does not have a dedicated work team for that purpose. Moreover, the person within the Unit who is responsible for processing any applications regarding anti-dumping, safeguards and countervailing measures is not exclusively assigned to this task, but also performs duties specific to the MEIC's UAJ. On the other hand, while legal work is carried out by the Legal Affairs Unit, technical investigations 
are submitted to the MEIC's Economic Department, a task it also has to fulfill in addition to its respective responsibilities. ${ }^{16}$

It should be noted that although the Office ceased operations in the year 2000, on August 23, 2002, the Ministry of Economy, Industry and Trade issued a new decree mandating its creation with legal personality. This time it would report to the Office of the Minister and was given exclusive responsibility over cases involving unfair trade practices and safeguard measures, except those cases where international treaties grant powers to other departments; but even under those circumstances, these departments would work in cooperation with the Office.

Pursuant to this new decree, several tasks and duties were assigned to the Office, namely:

- Receiving and processing complaints concerning dumping and subsidies, as well as applications for the imposition of safeguard measures.

- Conducting studies or investigations to determine the validity of the complaints and the need to impose measures.

- Advising the Minister and other areas of the Ministry on these matters.

- Advising industries on the operation of the Office.

- Providing guidance to interested parties on the appropriate use of international protection instruments.

- Advising interested parties on the proper filing of a complaint and the gathering of relevant evidence.

Although the institution of the Office is clearly outlined in the above-mentioned decree, it has not yet been created. Investigation processes are still carried out by the Legal Affairs Unit of the Ministry of Economy, Industry and Trade.

According to Mr. Douglas Alvarado, responsible for these matters at the MEIC's Legal Affairs Unit, in spite of the fact that the order for the re-establishment of the Office dates back to almost two years ago, the financial resources required are not available, there is a lack of specialized staff and there is little support to domestic industries due to the shortage of professionals specializing in international trade in the market, capable of advising businesses during the complaint process. Such limitations pose an enormous challenge for Costa Rica, since the various free trade agreements have given rise to a multiplicity of rules and provisions that demand a more robust and efficient institutional structure capable of properly managing their enforcement.

In this sense, Mr. Alvarado pointed out that it would be advisable to consider the alternative of creating this investigating office by law rather than by decree, with the purpose of reducing the involvement of political interests to a minimum. Lucrecia Brenes, a specialized private advisor, fully agreed with that opinion.

\footnotetext{
${ }^{16}$ Based on an interview with Mr. Douglas Alvarado, currently responsible for processing applications related to anti-dumping, safeguards and countervailing measures.
} 
Furthermore, it should be noted that apart from the MEIC, the country's institutional framework also comprises the Ministry of Foreign Trade (COMEX, in Spanish), which is responsible for notifying cases to the WTO, while the Ministry of Finance, through the Customs Directorate-General (DGA, in Spanish), is in charge of the implementation of the measures on imports. Although Costa Rica's experience in the application of safeguard and anti-dumping measures is limited to a single case (jute sacks), the performance of the DGA in this case raises doubts on the quality of the country's interinstitutional coordination to implement this type of measure adequately. ${ }^{17}$

While the imposition of safeguards and anti-dumping measures is part of the enforcement of the trade agreements to which the country is a party and the Ministry of Foreign Trade has an office to this end, it seems that in order to guarantee a better implementation of such measures by Customs it is necessary to strengthen the inter-institutional coordination role to be played by the COMEX.

\footnotetext{
${ }^{17}$ In the jute sacks case, although the measure should be implemented for only 30 days, it was applied by Customs during 6 months.
} 


\title{
SECTION IV
}

\author{
Costa Rica's Experience with \\ Anti-Dumping and Safeguard Cases
}




\section{4.a A Case Study of Complaints about Alleged Dumping Practices}

From 1995 to date (2004), the MEIC's Investigating Authority has received six complaints about alleged dumping practices, which will be analyzed below. ${ }^{18}$ Out of these, four concerned the manufacturing sector (Chapters 25 to 99 of the Central American Tariff System - SAC), while only two of the cases involved the agricultural and agroindustrial sectors (Chapters 01 to 24 of the SAC) ${ }^{19}$ This distribution is consistent with Costa Rica's import structure, which-as a consequence of the high tariff protection prevailing over the most important agricultural products for domestic consumption-is mostly concentrated on manufactured products.

Table 4.1 Costa Rica: Dumping Cases

\begin{tabular}{|c|c|c|c|c|}
\hline Year & Product & Sector & Related Countries & Complainant or Applicant \\
\hline 1995 & Acrylic sheets & Manufactures & Mexico & Acrílicos de Centroamérica S.A. \\
\hline 1996 & Refrigerators & Manufactures & Mexico & Atlas Industrial S.A. \\
\hline 1996 & Fresh onions & Agriculture & USA, Nicaragua and Guatemala & National Association of Onion Producers \\
\hline 1996 & Fiber cement sheets & Manufactures & Mexico & Ricalit S.A. \\
\hline 1997 & Pasta & Agroindustry & Chile & Pastas Roma S.A. \\
\hline 1998 & Sanitaryware & Manufactures & Venezuela & Standard S.A. \\
\hline
\end{tabular}

Source: Prepared by the authors based on data drawn from the resolutions on the dumping cases dealt with by the MEIC.

It is also worth pointing out that all of the complaints relate to imports originating in countries of the Americas; Mexico stands out for having three complaints against it, while two concern South American countries, and one, the United States together with two Central American countries.

This structure is extremely interesting since, although Mexico is not a prominent trade partner for Costa Rica, it is clear that the trade liberalization stemming from the Free Trade Agreement signed by both nations in 1995 revitalized trade links to a sufficient extent for Costa Rica's producers engaged in supplying the domestic market to pay much more attention to the prices offered by Mexican suppliers.

Moreover, of the six applications filed with the Investigating Authority, no dumping injury was found in two cases; two cases were dropped due to failure to submit the required information; in one case no measure was applied because it was not confirmed that the injury was directly caused by the imports, and only in one case it was decided to apply a tariff measure, which ended up being $0 \%$ since the imports virtually disappeared.

\footnotetext{
${ }^{18}$ No complaints about alleged dumping practices or applications for countervailing measures were filed in Costa Rica prior to 1995.

${ }^{19}$ The Central American Tariff System is derived from the Harmonized System and, therefore, it coincides with the latter as regards the first six digits of the headings or less.
} 
Table 4.2 Costa Rica: Summary Table of the Outcome of Dumping Cases Dealt With by the Investigating Authority

\begin{tabular}{|c|c|c|c|c|c|c|c|c|}
\hline \multirow[b]{2}{*}{ Product } & \multirow{2}{*}{$\begin{array}{c}\text { Firms } \\
\text { failed to } \\
\text { submit } \\
\text { information }\end{array}$} & \multirow[b]{2}{*}{$\begin{array}{c}\text { Case dropped by } \\
\text { applicant }\end{array}$} & \multirow[b]{2}{*}{$\begin{array}{c}\text { Initiation of } \\
\text { investigation }\end{array}$} & \multirow[b]{2}{*}{ Withdrawal $^{1}$} & \multirow[b]{2}{*}{$\begin{array}{l}\text { No injury } \\
\text { found }\end{array}$} & \multirow[b]{2}{*}{$\begin{array}{l}\text { Precautionary } \\
\text { measure }\end{array}$} & \multicolumn{2}{|c|}{ Final resolution } \\
\hline & & & & & & & $\begin{array}{c}\text { Measure } \\
\text { applied }\end{array}$ & $\begin{array}{c}\text { No } \\
\text { measure } \\
\text { applied }^{2}\end{array}$ \\
\hline Acrylic sheets & $\mathrm{X}$ & $\mathrm{X}$ & $\mathrm{X}$ & & $\mathrm{X}^{3}$ & & & \\
\hline Refrigerators & & & $\mathrm{X}$ & $\mathrm{X}^{4}$ & $\mathrm{X}$ & & & \\
\hline Fresh yellow onions & & & $\mathrm{X}$ & & & & & $\mathrm{X}$ \\
\hline Fiber cement sheets & $\mathrm{X}$ & $X$ & & & & & & \\
\hline Pasta & $\mathrm{X}$ & $\mathrm{X}$ & & & & & & \\
\hline Sanitaryware & & & $\mathrm{X}$ & & & & $X^{5}$ & \\
\hline
\end{tabular}

Source: Prepared by the authors based on data drawn from the resolutions on the dumping cases dealt with by the MEIC.

Due to space limitations, only one of the six cases of dumping reported in Costa Rica is described below for illustration purposes.

\section{4.a.1 The Refrigerators Case}

In October 1996, the company Atlas Industrial S.A. applied for a dumping investigation against imports of refrigerators (classified under item 84.18.21.00 of the SAC) originating in Mexico.

The applicant company argued that from May to September 1996 these imports had entered Costa Rica under dumping conditions, which, together with the fact that domestic and imported models are classified as homogenous and under the same tariff heading, in its judgment, gave rise to the conditions required to initiate an investigation. The company further argued that it accounted for $100 \%$ of the domestic production of refrigerators, and was therefore representative of the domestic industry involved.

In March 1997, Atlas Industrial S.A. withdrew the case, arguing that it had reached an agreement with the importing firm. However, a few days later the MEIC required Atlas to produce documentation evidencing such agreement, but Atlas did not provide any documents, indicating that the agreement had been of an informal nature, for which reason the MEIC considered it appropriate to continue the investigation on its own initiative. $^{20}$

It is interesting to note that both the Mexican exporter (Mabe S.A. de C.V.) and its importing counterpart in Costa Rica (Mabeca, the sole importer of refrigerators from

${ }^{20}$ Agreements between the parties must involve the Government and the importing or exporting firm, wherefore the "deal" between the domestic producer and the exporting company outside the legal framework governing such arrangements was considered illegal. For that reason, the MEIC decided to continue the investigation on its own initiative, since it considered that national interests could be compromised, and also submitted the case to the Commission on the Promotion of Competition. 
Mexico at the time of the investigation) submitted all the documentation required by the Investigating Authority, as opposed to Atlas, which did not.

The Investigating Authority determined that refrigerator imports from Mexico accounted for $35.5 \%$ of the total imports of that product in 1996. Besides, it found evidence of dumping on those imports, which was estimated to be $32 \%$ over the product's normal value. This result is not apparent in the figures of Table 4.3, where it may be seen that the value in US dollars per unit of weight (kilogram) of refrigerator imports, originating both in Mexico and the rest of the world, significantly increased in 1996, this increase being greater in the case of Mexico (32\%) than in the case of the rest of the world (4\%).

Table 4.3 Costa Rica: Refrigerator imports 1994-2002

(Figures in dollars and kilograms)

\begin{tabular}{|r|c:c|r|r|r|r|}
\hline \multirow{2}{*}{ Year } & \multicolumn{3}{|c|}{ Mexico } & \multicolumn{2}{c|}{ Rest of the world } \\
\cline { 2 - 7 } & Value & Volume & US\$/Kg & Value & Volume & US $\$ / \mathrm{Kg}$ \\
\hline 1994 & 562,756 & 138,409 & 4.07 & $9,317,673$ & $2,156,017$ & 4.32 \\
1995 & 638,105 & 168,393 & 3.79 & $6,846,208$ & $1,533,760$ & 4.46 \\
1996 & $1,777,664$ & 355,587 & 5.00 & $6,640,731$ & $1,426,152$ & 4.66 \\
1997 & $2,376,751$ & 548,106 & 4.34 & $7,525,276$ & $1,718,870$ & 4.38 \\
1998 & $2,101,208$ & 609,683 & 3.45 & $8,688,999$ & $2,056,394$ & 4.23 \\
1999 & $2,850,069$ & 904,441 & 3.15 & $9,068,508$ & $2,372,896$ & 3.82 \\
2000 & $2,610,767$ & 780,547 & 3.34 & $8,624,939$ & $2,385,894$ & 3.61 \\
2001 & $2,588,674$ & 727,741 & 3.56 & $12,773,567$ & $3,128,140$ & 4.08 \\
2002 & $4,245,819$ & $1,185,072$ & 3.58 & $16,877,366$ & $4,491,867$ & 3.76 \\
2003 & $5,358,228$ & $1,500,316$ & 3.57 & $13,356,334$ & $3,657,160$ & 3.65 \\
\hline
\end{tabular}

After reviewing the available information, the Investigating Authority concluded that there was no evidence to believe that the increase of imports under dumping conditions was causing injury to domestic production, and that, in its judgment, the decrease in Atlas' profits was primarily due to the reduction in the "other income" account, which dropped by $68 \%$ during the period in question. In other words, the erosion of Atlas's profits was the consequence of a reduction of income different from that derived from its sales of refrigerators in the domestic market and therefore could not be linked to the entry of imports under dumping conditions.

Table 4.4 Costa Rica: Refrigerator imports 1995-1996

(In units)

\begin{tabular}{|c|c|c|c|}
\hline Total & Aug-Dec & Jan-Apr & May-Sep \\
imported & 1995 & 1996 & 1996 \\
\cline { 2 - 4 } units & 422 & 356 & 2561 \\
\hline
\end{tabular}

Source: MEIC's resolution published in the Official Gazette.

Consequently, the MEIC concluded the investigation in September 1997 without imposing anti-dumping duties on the imports of refrigerators from Mexico. It is also worth noting that the Investigating Authority proceeded to notify the Commission on the Promotion of Competition so that it would investigate the agreement reached by the 
parties involved, under the assumption that the two companies might be colluding to implement discriminatory practices to the detriment of free trade.

\section{4.b A Case Study of the Applications for the Imposition of Safeguard Measures}

Between 1995 and 2004, the MEIC's Investigating Authority received a total of five applications for the imposition of safeguard measures, four of which involved manufactured products (classified under Chapters 25 to 99 of the Central American Tariff System) and one the agricultural sector, specifically milled and paddy rice. ${ }^{21}$

This distribution is approximately consistent with Costa Rica's import structure, since as a result of the high tariff protection prevailing over the most important agricultural products for domestic consumption, imports tend to be primarily manufactured products.

It is also worth pointing out that, out of the five applications, one was filed against imports from Asian countries, four against imports from countries in the Americas, and one against imports from Europe. ${ }^{22}$ This is consistent with the structure of Costa Rica's imports by origin, since virtually two thirds of them originate in North and Central America.

Table 4.5 Costa Rica: Safeguard Cases

\begin{tabular}{|c|c|c|c|c|}
\hline Year & Product & Sector & Related Countries & Complainant or Applicant \\
\hline 1995 & Bast fiber sacks & Manufactures & Nicaragua, India and Bangladesh & National Cabuya Board \\
\hline 1996 & Used Apparel & Manufactures & United States & Textile and Apparel Industry Association \\
\hline 1996 & $\begin{array}{c}\text { Ceramic blocks and } \\
\text { tiles }\end{array}$ & Manufactures & Spain, Italy, Brazil and Mexico & $\begin{array}{c}\text { Productos de Concreto S.A. y Firenze Industrial } \\
\text { S.A. }\end{array}$ \\
\hline 1996 & Sanitaryware & Manufactures & Mexico & Incesa Standard S.A. \\
\hline 2000 & $\begin{array}{c}\text { Milled and paddy } \\
\text { rice }\end{array}$ & Agriculture & United States & Rational Rice Board \\
\hline
\end{tabular}

Source: Prepared by the authors based on data drawn from the resolutions on the cases dealt with by the MEIC.

Furthermore, it is interesting to note that in only one of the cases (ceramic blocks and tiles) an investigation failed to be initiated since the applicant firms dropped the case and, therefore, did not submit the information required by the Investigating Authority. In only two of the five applications injury to domestic production caused by imports was found and, although in both cases it was decided to apply a provisional measure, only in one (jute sacks) was the measure finally imposed, since in the case of rice the application of the measure was not deemed necessary in view of the increase in the international prices of this grain, which made imports less attractive.

\footnotetext{
${ }^{21}$ No application of this type was submitted prior to 1995.

22 The total number of cases classified by regions is six since the ceramic blocks and tiles case involves countries from the Americas (Mexico and Bra zil) as well as European countries (Italy and Spain).
} 
Table 4.6 Costa Rica: Summary Table of the Outcome of Safeguard Cases Dealt With by Investigating Authority

\begin{tabular}{|c|c|c|c|c|c|c|c|c|}
\hline \multirow[b]{2}{*}{ Product } & \multirow{2}{*}{\begin{tabular}{c|} 
Firms \\
failed to \\
submit \\
information
\end{tabular}} & \multirow[b]{2}{*}{$\begin{array}{l}\text { Case dropped by } \\
\text { applicant }\end{array}$} & \multirow[b]{2}{*}{$\begin{array}{l}\text { Initiation of } \\
\text { investigation }\end{array}$} & \multirow[b]{2}{*}{ Withdrawal $^{6}$} & \multirow[b]{2}{*}{$\begin{array}{l}\text { No injury } \\
\text { found }\end{array}$} & \multirow[b]{2}{*}{$\begin{array}{c}\text { Precautionary } \\
\text { measure }\end{array}$} & \multicolumn{2}{|c|}{ Final resolution } \\
\hline & & & & & & & $\begin{array}{c}\text { Measure } \\
\text { applied }\end{array}$ & $\begin{array}{c}\text { No } \\
\text { measure } \\
\text { applied }^{1}\end{array}$ \\
\hline Bast fiber sacks & & & $\mathrm{X}$ & & & $\mathrm{X}$ & & $\mathrm{X}$ \\
\hline Used apparel & & & $\mathrm{X}$ & & & & & $X^{2}$ \\
\hline $\begin{array}{l}\text { Ceramic blocks and } \\
\text { tiles }\end{array}$ & $\mathrm{x}$ & $\mathrm{x}$ & & & & & & \\
\hline Sanitaryware & & & & & $\mathrm{X}^{3}$ & & & \\
\hline $\begin{array}{l}\text { Milled and paddy } \\
\text { rice }\end{array}$ & & & & & $X^{4}$ & & & \\
\hline
\end{tabular}

Source: Prepared by the authors based on data drawn from the resolutions on the cases dealt with by the MEIC.

Due to space limitations, only one of the five cases in which an application for the imposition of safeguards was filed in Costa Rica will be described below for illustration purposes.

\section{4.b.1 The Jute Sacks Case}

In September 1995, the National Cabuya Board filed an application for an investigation to impose a safeguard measure against imports of bast fiber sacks - classified under item 63.05.10.00 of the Central American Tariff System-originating in Nicaragua, Bangladesh and India.

The National Cabuya Board requested this measure because ofthe massive increase in imports of jute sacks, mainly from Bangladesh, arguing that this situation directly affected both the domestic production of cabuya sacks and the marketing of coffee, since jute and cabuya sacks are used to package coffee for export.

In the application, the requesting party mentioned that Bangladesh is the source of $55 \%$ of the world's exports of jute, while Costa Rica's production amounts to less than $0.2 \%$ of the Bangladesh production; this situation could cause serious injury to the domestic production of cabuya sacks. Furthermore, the National Cabuya Board noted that Bangladesh granted its exporters subsidies covered under the WTO agreements. ${ }^{23}$

During the investigation of this case, the Investigating Authority found that most of the import flows affecting the sector originated in Nicaragua, but that in the year 1995 Bangladesh had been the origin of around $40 \%$ of Costa Rica's total imports of this product, a significant figure since in 1994 Bangladesh had not exported a single sack to Costa Rica.

\footnotetext{
${ }^{23}$ The MEIC indicated that when unfair trade results from the granting of a subsidy in the exporting country, the proper measure is a countervailing duty rather than a safeguard.
} 
The data shown in the following table for imports of cabuya sacks per country of origin draws attention to the fact that in 1995 Nicaragua increased its exports to Costa Rica more than twofold compared to the previous year. This situation, together with the large increase of imports from other countries (including Bangladesh), meant an aggregate increase of $290 \%$ in the total imports of cabuya sacks to Costa Rica in that same year.

Table 4.7 Costa Rica: Origin of cabuya sacks imports 1992-1995

(In -units)

\begin{tabular}{|c|r|r|r|}
\hline Year & $\begin{array}{c}\text { Total imported } \\
\text { sacks }\end{array}$ & $\begin{array}{c}\text { Sacks imported } \\
\text { from Nicaragua }\end{array}$ & \multicolumn{2}{|c|}{$\begin{array}{c}\text { Sacks imported from } \\
\text { Bangladesh and other } \\
\text { countries }\end{array}$} \\
\hline 1992 & 371,490 & 332,409 & 39,081 \\
\hline 1993 & 286,582 & 253,596 & 32,986 \\
\hline 1994 & 209,218 & 209,218 & 0 \\
\hline 1995 & 816,683 & 489,609 & 330,074 \\
\hline
\end{tabular}

Note: The periods correspond to January-August of each year.

Source: MEIC's resolution published in the Official Gazette No. 91, May 13, 1998.

These figures confirm the substantial increase in imports that would result in the eventual injury to the domestic production of jute sacks. Unfortunately, the case's file and the respective MEIC's resolution fail to provide any information or analysis of the impact (if any) of said increased imports on the domestic production of jute sacks.

Likewise, there are no data available on the sector's evolution or its share in production and employment. However, given that one of the main uses of jute sacks is to package coffee for export, the behavior of coffee exports could well shed some light on the potential impact of the increased imports of cabuya sacks on domestic production.

According to figures from the Central Bank of Costa Rica, the volume of coffee exports (in 46-kilogram sacks) decreased by $3 \%$ in 1995, which is consistent with most of the years of that decade, with the exception of 1996, when the volume of coffee exports recorded an increase of $23 \%$. Taking into account that jute sacks are ot a perishable product and that coffee is usually traded in futures markets, it makes sense to consider that the increase in the volume of coffee exports in 1996 would explain part of the increase in jute sacks imports in 1995.

That means that around one tenth of the increased cabuya sacks imports recorded in 1995 had no direct effect on domestic production, since it was simply meeting an increase in the demand for the product to be used to package coffee for export. ${ }^{24}$ However, even though there is no information on the behavior of the other activities that use jute sacks as an input, it seems reasonable to assume that the remaining 267 percentage points of increase in jute sacks imports did cause an important crowding out of domestic production in the local market.

\footnotetext{
24 Indeed, the positive expectations created by the increased sales of coffee abroad could have induced coffee businesses to increase their stock of packaging material.
} 
Based on the investigation, the Ministry of Economy, Industry and Trade (MEIC, in Spanish) finally decided to apply a provisional measure that would be a tariff increase from $54 \%$ to $140 \%$ for a period no longer than 30 days. The implementation of the measure implied that the National Cabuya Board would commit itself to improving the use of the established capacity and production in order to have a better situation once the measure expired, an aspiration that does not seem quite reasonable because it entails long-term aspects that require much more than 30 days.

It is equally interesting to point out that the Investigating Authority also determined that, although it was true that there had been a substantial increase in cabuya sacks imports in 1995, to a great extent this was a response to the lack of supply in the domestic market, because since 1992, domestic production failed to meet domestic demand.

In 1997, the MEIC lifted the provisional measure that had been imposed based on the realization that its application had gone on for over six months, when it actually should have only been applied for 30 days. Therefore, and after verifying that the domestic industry had not made anyadjustments or improvements, the MEIC finally decided to close the investigation in April 1998, and not to impose any final measure.

This confirms that, although the imposition of the safeguard measure does not seem to have stemmed from protectionist intentions, its incorrect implementation did provide a margin of protection beyond what was contemplated.

\section{4.c Summing Up}

The figures in Table 4.8 show that the applications for the imposition of safeguards and anti-dumping measures have mostly focused on manufactured goods, not surprising in view of the fact that Costa Rica still retains a high protection rate for basic consumption agricultural products.

Table 4.8 Costa Rica: Summary of Cases Dealt With by the Investigating Authority

\begin{tabular}{|c|c|c|c|c|}
\hline \multirow{2}{*}{\multicolumn{2}{|c|}{ Measures }} & \multicolumn{2}{|c|}{ Sectors } & \multirow[b]{2}{*}{ Total } \\
\hline & & Manufactures & Agriculture & \\
\hline \multirow{3}{*}{$\begin{array}{l}\text { Safeguards } \\
\text { Antidumping }\end{array}$} & & 4 & 1 & 5 \\
\hline & & 4 & 2 & 6 \\
\hline & Total & 8 & 3 & 11 \\
\hline
\end{tabular}

Source: Prepared by the authors based on data drawn from the resolutions on cases dealt with by the MEIC.

By the same token, Figure 4.1 shows that the applications for the imposition of measures not only have been rather balanced between safeguard and anti-dumping measures, but also have had a relative lag between the date of entry into force of the rules (1995) and the year when the last case was submitted (2000). 
Figure 4.1 Costa Rica: Summary of Cases Dealt With by the Investigating Authority

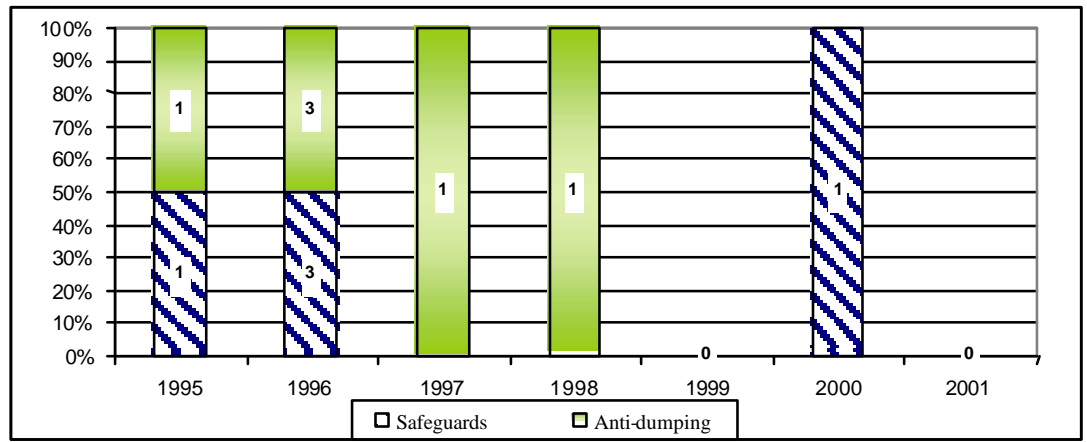

Source: Prepared by the authors based on data drawn from the resolutions on cases dealt with by the MEIC.

Although elements such as failure to produce information by the applicant companies and the results of the statistics reported in this document suggest that several of the applications for the imposition of safeguard or anti-dumping measures seem to have merely responded to protectionist interests; the case of milled rice is the only one where there appears to have been an economic policy scenario that somehow influenced the final imposition of measures. In this case, the technical criterion of the Investigating Authority indicated that a measure was not warranted, but even so the MEIC's authorities decided to impose a provisional safeguard. The decision was influenced by the strong pressure that local producers brought to bear on the competent authorities involved. ${ }^{25}$ Indeed, in a later review of the case by the General Controllership of the Republic, serious deficiencies were found in the procedure for the adoption of the final resolution issued by the MEIC.

Another important element to be underlined is the fact that in those cases in which the Investigating Authority carried out the investigation process, the contents of the files revealed a rather superficial economic analysis of the cases. In fact, this made it necessary for the authors of this paper to search for statistics that could at least give an approximate idea of the relevant economic environment in which each of the investigations following the applications took place, since in general the files are lacking in figures and analysis.

Summarizing, it cannot be asserted that there is evidence in the sense that Costa Rica's institutional structure to process applications for safeguard and anti-dumping measures was working perfectly. Furthermore, an individual and detailed analysis of the cases leads to the conclusion that actually there have been attempts, albeit failed ones, to use such measures in Costa Rica with protectionist purposes. As a corollary to all these, it may be said that Costa Rica has made a reasonable use of such instruments to date.

\footnotetext{
25 A review of the press reports of the year 2000 is sufficient evidence of the pressure exerted by the producers of this grain on the Government of the day.
} 


\section{FINAL CONSIDERATIONS}

Although the process of economic liberalization initiated by Costa Rica in the second half of the 1980s has not yet been completed, because there are still important sectors that enjoy protection against foreign competition (mainly telecommunication services, insurance and some agricultural products), it may be asserted that, from an economic perspective, at the beginning of the 21 st century Costa Rica is very different from the Costa Rica of the early 1980s. At that time, the economy was characterized by a preponderance of two export crops as major sources of foreign exchange earnings (coffee and bananas), a limited inflow of foreign investment and the participation of the state in many diverse productive activities, all of the above as a result of an import-substitution development model, which also generated rent-seeking activities that are not directly productive (Bhagwati, 1982) and, therefore, important losses in terms of welfare for the majority of Costa Ricans (Monge and González, 1995).

Today, 20 years later, Costa Rica is characterized by the diversification of its exports (in terms of products, firms and destinations), trade liberalization (reduction of import barriers), the consolidation of a tourism industry cluster, the entry of important flows of foreign investment, mainly high-tech, and a decrease in the direct participation of the state in some productive activities. ${ }^{26}$ To a great extent, all of these results can be attributed to the economic liberalization process initiated by Costa Rica in the mid 1980s, designed and implemented under the rule of law in a democratic regime.

The performance of Costa Rica's economy over the period 1986-2003 may be considered satisfactory, since it exhibits important transformations in its production system, as well as improvements in the fight against poverty, the generation of new sources of employment and the lack of deterioration of income distribution.

The empirical evidence on safeguards and unfair competition policies shows that the country has had to respond to very few complaints in this field (11 in total). After analyzing each of these complaints, it may be argued that there have been attempts by some companies or business organizations to seek new forms of protection against imports during the economic liberalization period. However, Costa Rica's government has been very careful in handling these requests and has acted in accordance with the standards established in the relevant legal instruments, thus avoiding an undue application of such instruments. The exception to the rule has been the case of rice, where it seems that the result of the complaint did respond to political pressures, which, according to the political economy theory, results from the search for directly unproductive, profit-seeking (DUP) activities by the companies involved.

It should be noted that in the case of manufacturing companies, although the applicant firms settled in Costa Rica under the umbrella of the previous import-substitution model,

\footnotetext{
${ }^{26}$ It is worth pointing out that the Government of Costa Rica stopped participating in productive activities such as those of cement and ethyl alcohol by privatizing the respective State companies. For a detailed analysis, see Dennis Meléndez H. and Mauricio Meza R. 1993. CODESA: origen y consecuencias. San José: Fiduciaria de Inversiones Transitorias (FINTRA).
} 
currently many of then have succeeded in completing an important transformation and have become exporters (for example, Atlas Industrial and Pastas Roma) for which foreign markets count. Contrary to this, many agricultural activities that brought complaints about unfair trade practices or safeguards are still highly protected in Costa Rica (for example, onions, which even succeeded in being excluded from the Central American Free Trade Agreement - CAFTA).

Regarding the evolution of the legal rules on dumping and safeguards in force in Costa Rica, the review conducted in this paper clearly indicates that through the process of negotiation of bilateral free trade agreements, Costa Rica has improved its rules governing these matters, particularly in terms of providing faster and more transparent mechanisms to process applications, as well as reducing the timeframes during which such measures may be imposed and remain effective.

In the specific case of safeguard measures, elements such as the security that has to be deposited by the applicant in the case of the imposition of a provisional measure within the framework of the Central American Regulations on this matter, or the compensation in the form of tariff concessions that has to be offered to the other party against the imposition of a safeguard in the framework of the bilateral free trade agreements signed to date, clearly reveal that the rules have included the necessary provisions to prevent domestic companies from carelessly requesting the application of safeguard measures merely with protectionist purposes.

In the analysis of the institutional arrangements and the procedures that need to be followed by applicant businesses, it was found that the forms they have to fill out are not complex to the point to be inaccessible for the companies, although completing them does require time and some knowledge on the subject. The need for expertise is important, since it was revealed by the interviews with MEIC's officials and representatives of Costa Rica's business sector that the country lacks sufficient skilled human resources to adequately advise the private sector on how to file applications for the imposition of anti-dumping and safeguard measures.

Furthermore, it still seems to exist an important gap in the institutional framework, particularly in the MEIC, to appropriately deal with this type of complaint. In fact, currently there is no specialized office to take care of these applications due to the low number of complaints that have been filed. For that reason, the cases are referred to the MEIC's legal department. This limitation is being analyzed by Costa Rica's authorities, trying to strike a balance between the private sector's needs in this regard and the opportunity cost of the resources available at the Ministry to discharge all of its responsibilities.

In that respect, a possibility to be explored is transferring the responsibility for processing unfair trade practices complaints and safeguard applications to the Ministry of Foreign Trade (COMEX, in Spanish), since the COMEX is the agency in charge of managing trade agreements (multilateral and bilateral) signed by Costa Rica, both in terms of the 
free trade agreements and the country's obligations under the WTO, besides having a budget for such purposes.

Summarizing, Costa Rica has succeeded in making progress toward economic liberalization during the last 20 years without having to face economic crises; it has effectively fought against poverty and confronted important flows of immigration and maintained low and stable levels of unemployment and underemployment, all without a deterioration of income distribution. Moreover, the country has successfully managed to respond to complaints about unfair trade practices and substantial increases in imports that can affect domestic production, appropriately differentiating authentic cases from those that would seem to be new protectionist endeavors. However, Costa Rica still faces an important challenge to efficiently manage its commitments and responsibilities in terms of anti-dumping and safeguard policies, as a result of lacking appropriate institutional arrangements. 


\section{BIBLIOGRAPHIC REFERENCES}

Balassa, Bela (1971). The structure of protection in developing countries. Baltimore: The Johns Hopkins University Press.

Bhagwati, Jagdish (1982). "Directly unproductive, profit seeking (DUP) activities", in Journal of Political Economy, Vol. 88, August, pp 409-33

- (1991). Political Economy and International Economics. Cambridge, Massachusetts: MIT Press.

Céspedes, Víctor and Ronulfo Jiménez. (1997). Costa Rica: una economía en recesión. Informe sobre la economía en 1996. San José: Academia de Centroamérica.

Corrales Quesada, Jorge (1993). 'Política comercial reciente en Costa Rica", in Jorge Corrales (ed.), Raíces Institucionales de la Política Económica Costarricense. San José: CIAPA.

Corrales, Jorge and Ricardo Monge (1990). Exportaciones no tradicionales en Costa Rica. San José: Econofín.

Edwards, Sebastian (1990). “Ajuste Cambiario y Equilibrio Macroeconómico en Costa Rica: Lecciones y Perspectivas”, in Claudio González Vega and Edna Camacho. (eds.), Políticas Económicas en Costa Rica. Volume II. San José: Academia de Centroamérica and Ohio State University.

González Vega, Claudio (1984). "Fear of adjusting: the social costs of economic policies in Costa Rica in the 1970's", in Donald Shutz and Douglas Graham (eds), Revolution and Counterrevolution in Central America and the Caribbean. Boulder: Westview Press.

(1989). "Debt, Stabilization and Liberalization in Costa Rica: Political Economy Responses to a Fiscal Crisis", in Latin America Debt and Adjustment, edited by Philip L. Brock, Michael Connolly and Claudio González Vega. New York: Praeger.

IMF (1998). Costa Rica: recent economic developments. IMF Staff Country Report No. 98/45. Washington: International Monetary Fund.

Lerner, A.P. (1936). "The symmetry between import and export taxes", in Económica. Vol. 3, No. 11 (August). Reprinted and revised in Readings in International Economics, edited by Richard Caves and Harry Jonson. Homewood. Illinois: Richard D. Irwin, Inc. (1968). 
Lizano Fait, Eduardo (1992). Estado y Economía en América Central. Paper prepared for the Congreso Internacional sobre Estado en América Latina: Orden Democrático, Cambio Sistemático y Perspectivas. Asociación Alemana de Investigación en América Latina. Mimeo.

Mesalles, Luis (1998). "Condiciones Macroeconómicas de la Economía Costarricense", in Estabilidad y Desarrollo en Costa Rica. Las Reformas Pendientes. San José: Academia de Centroamérica.

Monge, Ricardo (1987). La Reforma Arancelaria: El Caso de Costa Rica. Prodesarrollo. San José.

(1992). Welfare Effects of Trade Restrictions Removal: a Costa Rica Case Study. Master Thesis. The Ohio State University, Ohio.

(1994). The Political Economy of Trade Reform in Costa Rica. Doctoral dissertation. The Ohio State University, Ohio.

Monge, Ricardo and Claudio González-Vega (1995). Economía Política, Proteccionismo y Apertura en Costa Rica. San José, Costa Rica: Academia de Centroamérica and Centro Internacional para el Desarrollo Económico.

Monge, Ricardo and Eduardo Lizano (1997). Apertura Económica e Industrialización en Costa Rica. Academia de Centroamérica. San José: Costa Rica.

Monge, Ricardo and Jorge Corrales (1988). Políticas de Protección e Incentivos a las Manufactura. Agroindustria y Algunos Sectores Agrícolas en Costa Rica. San José: Econofín.

Monge, Ricardo, Julio Rosales and Gilberto Arce (2005). Cost-Benefit Analysis of the Free Trade Zone System: The Impact of Foreign Direct Investment in Costa Rica. OAS Trade, Growth and Competitiveness Studies, Washington D.C.: Organization of American States.

Oficina de Prácticas de Comercio Desleal y Medidas de Salvaguardia. Resoluciones de los casos antidumping y de imposición de medidas de salvaguardias. Archivo Central, Unidad de Asuntos Jurídicos, Ministerio de Economía, Industria y Comercio de Costa Rica.

Rhee, Yung Whee (1984). 'Framework for Export Policy and Administration: Lessons from the East Asian Experience". Industry and Finance Paper No. 10. Washington, D.C.: The World Bank.

Taylor, Marvin (1984). Estructura de la Protección al Sector Industrial en Costa Rica. San José. Prodesarrollo. 